\title{
Expression of RNA from developmentally important genes in preimplantation bovine embryos produced in TCM supplemented with BSA
}

\author{
C. Wrenzycki, D. Herrmann, J. W. Carnwath and H. Niemann* \\ Department of Biotechnology, Institut für Tierzucht und Tierverhalten (FAL), Mariensee, 31535 Neustadt, \\ Germany
}

This study investigated the effects of a semi-defined culture system on the temporal pattern of expression of RNA from genes involved in compaction and cavitation: gap junction protein connexin 43 (Cx43), desmosomal glycoproteins desmoglein 1 (Dg 1), desmocollins I, II and III (Dc I, Dc II, Dc III), desmosomal protein plakophilin (Plako); metabolism glucosetransporter-1 (Glut-1); RNA processing poly(A)polymerase (PolyA); heat shock protein 70.1 (HSP); and trophoblastic function trophoblast protein (TP) in bovine oocytes and embryos generated in vitro using TCM199 supplemented with BSA as the culture medium. Morulae and blastocysts derived in vivo were collected from superovulated heifers and also used for this study. Poly(A) ${ }^{+}$RNA was extracted from pools of 20-50 oocytes or embryos, analysed by reverse transcription-polymerase chain reaction and the amplified fragments were verified by sequencing. Assays were repeated at least three times for each developmental stage and provided consistent results in all replicates. In bovine embryos produced in vitro, mRNA encoding $\mathrm{Cx} 43$ was detectable up to the morula stage, whereas blastocysts and hatched blastocysts did not express this gene. No transcripts were found for Dg $I$ and Dc I throughout the tested preimplantation stages. Dc II and Dc III transcripts were found from 2-4-cell embryos up to the hatched blastocyst stage. mRNA encoding Plako was detected in immature and mature oocytes and zygotes, while no transcripts were seen in 2-4-cell and 8-16-cell embryos. The gene was expressed again from the morulae to the hatched blastocyst stage. Oocytes and bovine embryos produced in vitro showed transcripts for Glut-1, PolyA and HSP throughout preimplantation development up to the hatched blastocyst stage. The gene encoding TP was transcribed only in blastocysts and hatched blastocysts. Morulae and blastocysts produced in vivo showed the same expression as their in vitro counterparts, with one exception: the in vivo embryos transcribed Cx43. The results of this study reveal for the first time the transcriptional pattern of a set of 'marker' genes involved in various processes in early bovine embryonic development. Transferable morulae and blastocysts produced in vitro expressed most genes similar to their in vivo counterparts. These data contribute to the molecular characterization of this widely used in vitro culture system for bovine embryos and provide a major advance towards production of 'physiologically normal' embryos.

\section{Introduction}

In vitro production (IVP) of bovine embryos is a useful tool for basic embryological studies as well as commercial applications. Blastocyst developmental rates between $30 \%$ and $40 \%$ of the matured oocytes can be obtained with optimized IVP systems (Brackett and Zuelke, 1993; Trounson et al., 1994). In general, bovine embryos are cultured in media supplemented with serum often in a coculture with somatic cells (Bavister, 1995). Serum was found to have a biphasic influence on development of bovine embryos, inhibiting the first cleavage division but

*Correspondence. enhancing blastocyst development (Pinyopummintr and Bavister, 1991, 1994; Van Langendonckt et al., 1997). Serum has been replaced by BSA to achieve standardization and to improve repeatability. These semi-defined culture conditions for IVP may overcome the variability and the lack of reproducibility of developmental rates and embryo quality (see Bavister, 1995).

Compared with embryos obtained in vivo, embryos produced in vitro display marked differences, for example, in gross morphology, ultrastructure, colour, density, number of cells, size, developmental rate, temperature sensitivity, freezability, viability and pregnancy rates after transfer (Greve et al., 1994). Wrenzycki et al. (1996) have discovered a qualitative difference 
at transcription. Postimplantation events can be affected by culture conditions and are thought to be involved in the delivery of abnormally large fetuses or offspring upon transfer of bovine embryos grown in vitro (Kruip and denDaas, 1997). The most prominent correlation is that the high serum content of the media is a major factor related to this phenomenon (Thompson et al., 1995).

Preimplantation embryo development is characterized by distinct morphological steps such as compaction, cavitation, and blastocoel expansion, requiring the well-orchestrated expression of genes derived from the maternal and embryonic genome (Kidder, 1992). The burst of genomic activation of embryos grown in vitro occurs at the 8-16-cell stage (Telford et al., 1990), while some activation is seen at the 2-4-cell stage (Plante et al., 1994; Hyttel et al., 1996; Viuff et al., 1996; Bilodeau-Goeseels and Schultz, 1997a). However, RNA transcription of bovine embryos generated in vivo has already been detected at the 1-2-cell stage and appears to be downregulated at the transition from the 2- to the 4-cell stage or at the 4-cell stage (Hay-Schmidt et al., 1997). Embryos have been cultured in $\alpha$-amanitin (a potent inhibitor of RNA polymerase II) to determine the relative contribution of embryonic gene transcription to the overall transcripts in the early embryo. If transcription was sensitive to $\alpha$-amanitin, the transcript must be of embryonic origin. However, bovine embryos did not develop after treatment with $\alpha$-amanitin (Liu and Foote, 1997). Furthermore, requirements for synthesis of new proteins may also depend upon endogenous stores (Rambhatla and Latham, 1995).

Most of the currently available information on transcription of specific genes in preimplantation development stems from mice. In bovine embryo development, the majority of the information on transcriptional activity is derived from studies in which radiolabelled dUTP uptake is used (Camous et al., 1986; Kopecny et al., 1989; Plante et al., 1994; Hyttel et al., 1996; Viuff et al., 1996). However, with the improvement of IVP systems for bovine embryos (Trounson et al., 1994) and the availability of the highly sensitive reverse transcriptasepolymerase chain reaction (RT-PCR), information on the genetic activity of bovine embryos is growing and it is now feasible to characterize the transcriptional patterns of developmentally important genes (Watson et al., 1992; Harvey et al., 1995; Wrenzycki et al., 1996; Betts et al., 1997; Winger et al., 1997).

The genes analysed in this study were chosen to characterize the effects of a widely used IVP system on physiological processes involved in compaction and cavitation, glucose metabolism, RNA processing, stress and early differentiation. The gap junction protein connexin $43(\mathrm{Cx} 43)$ is necessary for the maintenance of compaction and, thus, for subsequent blastocyst formation in mice (Lee et al., 1987; Bevilacqua et al., 1989). Desmosomal junctions are part of the epithelial adhesion system involved in mouse blastocoel cavitation and play a role in stabilizing the trophectoderm as the blastocyst expands (Fleming et al., 1991; Collins et al., 1995). Desmosomes are composed of transmembrane glycoproteins, such as desmocollins and desmogleins, that are involved in intercellular adhesion, and several cytoplasmic proteins (desmoplakins, plakoglobin, plakophilin) forming the plaque structure and mediating anchorage of cytokeratin filaments (Schwarz et al.,
1991; Buxton et al., 1993; Garrod, 1993). Glucose plays an important role in embryonic metabolism. In the mouse blastocyst, most of the apparent glucose uptake is mediated by facilitative carriers, for example, glucosetransporters (Gardner and Leese, 1988; Gardner and Kaye, 1995). The poly(A) tail found at the $3^{\prime}$-ends of nearly all eukaryotic mRNAs is responsible for the initiation of translation and the regulation of mRNA breakdown (Jackson and Standart, 1990; Bachvarova, 1992). Synthesis of the poly (A) tail is carried out by a poly (A) polymerase (Takagaki et al., 1988; Wahle, 1991). During early development, increased temperatures, free radicals and oxygen stress have deleterious effects on embryonic viability and development (Ealy et al., 1993). Thermotolerance and resistance to protein denaturation in general is induced by a family of proteins referred to as heat shock proteins (HSPs). Maternal recognition of pregnancy is initiated by interferon $\tau$ (IFN $\tau$ ). IFN $\tau$, also named TP-I, is a major secretory protein produced by the trophoblast cells of the bovine blastocyst (HernandezLedezma et al., 1992; Watson et al., 1992) and plays an important role in pregnancy establishment via its antiluteolytic effect (Bazer et al., 1991).

Here we report the determination of the transcriptional pattern of ten genes involved in the physiological processes mentioned above in bovine preimplantation embryos generated under semi-defined culture conditions. Morulae and blastocysts collected from superovulated cows were included in this study as in vivo controls for the transferable stages.

\section{Materials and Methods}

\section{Production of bovine embryos in vitro}

Collection of cumulus-oocyte complexes. Bovine ovaries obtained from a local abattoir were transported in PBS (Sigma Chemical Co., St Louis, MO) at $25-30^{\circ} \mathrm{C}$ to the laboratory, where they were washed twice in fresh PBS. Cumulus-oocyte complexes (COC) were isolated via slicing (Eckert and Niemann, 1995). Briefly, ovaries were cut with razor blades in PBS containing $0.1 \%$ BSA (fraction V, Sigma) and 2 iu heparin (Serva, Heidelberg). The resulting suspension was passed through a filter to isolate the COC. Category I COC (with a homogeneous evenly granulated cytoplasm possessing at least three layers of compact cumulus cells) and category II COC (with fewer than three layers of cumulus cells or partially denuded but also with a homogeneous evenly granulated cytoplasm; Pavlok et al., 1992) were pooled in TCM-air (TCM199 containing L-glutamine and $25 \mathrm{mmol}$ Hepes $\mathrm{I}^{-1}$ (Sigma) supplemented with $22 \mu \mathrm{g}$ pyruvate $\mathrm{ml}^{-1}, 350 \mu \mathrm{g}$ $\mathrm{NaHCO}_{3} \mathrm{ml}^{-1}, 50 \mu \mathrm{g}$ gentamicin $\mathrm{ml}^{-1}$ and $1 \mathrm{mg} \mathrm{BSA} \mathrm{ml} \mathrm{m}^{-1}$ $($ fraction $\mathrm{V})$ ).

Maturation in vitro. TCM199 containing L-glutamine and $25 \mathrm{mmol}$ Hepes $\mathrm{l}^{-1}$ served as the basis for culture media. One millilitre was supplemented with $22 \mu \mathrm{g}$ pyruvate, $2.2 \mu \mathrm{g}$ $\mathrm{NaHCO}_{3}$ and $50 \mu \mathrm{g}$ gentamicin. For oocyte maturation, this medium was supplemented with $0.1 \%$ BSA (fraction V, Sigma), $1 \mu \mathrm{g}$ oestradiol $\mathrm{ml}^{-1}$ (Serva), $0.5 \mu \mathrm{g} \mathrm{FSH} \mathrm{ml}^{-1}$ (Folltropin ${ }^{\mathbf{R}}$, Vetrepharm, London, Ontario) and $0.06 \mathrm{iu} \mathrm{hCG} \mathrm{ml}^{-1}$ (human chorionic gonadotropin, Ekluton ${ }^{\mathbb{R}}$, Vemie, Kempen). 
Fresh COC were washed twice in TCM199 supplemented with $0.1 \%$ BSA (fraction V) and then divided in groups of $20-25$, transferred into $100 \mu \mathrm{l}$ maturation drops under silicone oil and cultivated in a humidified atmosphere composed of $5 \%$ $\mathrm{CO}_{2}$ in air at $39^{\circ} \mathrm{C}$ for $24 \mathrm{~h}$. After fixation and staining with acetic orcein, a representative sample of the oocytes was examined for the presence of metaphase II and the first polar body.

Fertilization in vitro. After in vitro maturation, $\mathrm{COC}$ were rinsed in fertilization medium (Fert-TALP supplemented with $6 \mathrm{mg} \mathrm{BSA} \mathrm{ml}^{-1}$ ) and fertilized in Fert-TALP containing $10 \mu \mathrm{mol}$ hypotaurine $1^{-1}$ (Sigma), $1 \mu \mathrm{mol}$ adrenalin $\mathrm{l}^{-1}$ (Sigma), 0.1 iu heparin $\mathrm{ml}^{-1}$ (Serva) (HHE) and $6 \mathrm{mg}$ BSA $\mathrm{ml}^{-1}$. Frozen semen from one bull of proven fertility was used for in vitro fertilization (IVF). For IVF, semen was prepared by a modified 'swim-up' procedure (Parrish et al., 1986, 1988). Briefly, semen was thawed in a waterbath at $37^{\circ} \mathrm{C}$ for $1 \mathrm{~min}$. After swim-up separation in Sperm-TALP containing $6 \mathrm{mg}$ BSA ml ${ }^{-1}$ for $1 \mathrm{~h}$, the semen was washed twice by centrifugation at $350 \mathrm{~g}$ and $36^{\circ} \mathrm{C}$ for $10 \mathrm{~min}$ before being resuspended in Fert-TALP supplemented with HHE and BSA. The final sperm concentration added per fertilization drop was $1 \times 10^{6}$ spermatozoa $\mathrm{ml}^{-1}$.

Fertilization occurred during a $18-20 \mathrm{~h}$ coincubation under the same temperature and gas conditions as described for maturation. Representative groups of fertilized oocytes were fixed and stained to control for the success of sperm-oocyte coincubation. Oocytes with two pronuclei and one sperm tail were considered as normally fertilized.

Culture in vitro. For in vitro culture, zygotes were transferred into $200 \mu \mathrm{l}$ drops of TCM199 with 0.1\% BSA (fraction $V)$. Culture was maintained for a maximum of 11 days under the same conditions as described above. A total of 3200 COC from 380 ovaries was used to produce a complete developmental series from the immature oocyte to the hatched blastocyst. Upon transfer, these bovine blastocysts produced in vitro yielded pregnancy rates of 50\% (Pavlok et al., 1992).

Immature and in vitro matured oocytes were treated with trypsin-EDTA to remove the cumulus cells. All oocytes or embryos were washed extensively and the absence of cumulus cells was verified at $\times 200$ magnification to ensure that the transcripts did not originate from residual cumulus cells.

Pools of immature (IO) and matured oocytes (MO), zygotes (Z), 2-4 cell (2-4), 8-16 cell embryos (8-16), morulae $(\mathrm{M})$, blastocysts (B) and hatched blastocysts (HB) were collected at the appropriate developmental times: $\mathrm{MO}$ after $24 \mathrm{~h}$ of maturation, $Z 18-20 \mathrm{~h}$ postinsemination (h.p.i.), 2-4 cell stages $44-46$ h.p.i., 8-16 cell stages $92-94$ h.p.i., M 140-142 h.p.i., B 188-190 h.p.i., HB 112-114 h.p.i. Oocytes and embryos were included in the experiments only when they were derived from IVP runs in which the following minimum developmental rates had been obtained: $70 \%$ IVM, $60 \%$ normal fertilization, $60 \%$ cleavage rate, $20 \%$ blastocysts. Oocytes or embryos that had not reached the expected developmental stage at the respective time points were discarded from this study.

\section{Production of bovine embryos in vivo}

Holstein Friesian donor cows were superovulated with a single intramuscular injection of 3000 iu pregnant mares' serum gonadotrophin (Brumegon ${ }^{\hat{\mathbb{R}}}$. Hydrochemie, Munich) between days 9 and 13 of the oestrous cycle followed $48 \mathrm{~h}$ later by Cloprostenol (Estrumate ${ }^{(\mathrm{i})}$, Pitman-Moore, Burgwedel). After $48 \mathrm{~h}$, the donors were inseminated twice at an interval of $12 \mathrm{~h}$ when superovulatory oestrus was detected. On day 7 after insemination, morula and blastocyst stages were recovered by nonsurgical flushing of the uterine horns with $300 \mathrm{ml}$ PBS plus 1\% newborn calf serum (NBCS, Number 295957; Boehringer, Mannheim) using established procedures.

\section{Preparation of oocyteslembryos for RT-PCR analysis}

Morphologically intact ova or embryos generated in vitro or in vivo were used for the experiments. Briefly, oocytes with an extruded polar body were considered to be matured. Fertilization was verified at $\times 320$ magnification by the presence of two polar bodies and two pronuclei. Two-four cell and 18-16 cell stages were identified by their round, fine granulated blastomeres. Embryos with coalesced blastomeres were considered as compacted morulae; embryos containing a clearly visible blastocoel cavity were considered as blastocysts; and hatched blastocysts were completely hatched from the zona pellucida. After washing three times in PBS containing 0.1\% PVA (polyvinyl alcohol, Sigma) they were stored in pools of $20-30$ at $-80^{\circ} \mathrm{C}$ in a minimum volume $(\leq 5 \mu \mathrm{l})$ of medium until use. RNA equivalents of I-10 oocytes/embryos were chosen for the PCR analysis in the present study as this strategy had been used successfully in numerous investigations using RT-PCR assays of similar sensitivity (Harvey et al., 1995; Davis et al., 1996; Fleming et al., 1997; Winger et al., 1997; Worrad and Schultz, 1997). In contrast, the less sensitive northern blot technology required pools of up to 360 embryos for RNA detection (Bilodeau-Goeseels and Schultz, 1997b). In addition, use of pooled material eliminates potential effects of the cell cycle on amounts of specific mRNAs (Moore et al, 1996).

\section{Isolation of RNA}

Poly $(\mathrm{A})^{+} \mathrm{RNA}$ was isolated using a Dynabeads mRNA DIRECT Kit (Dynal ${ }^{R}$, Oslo) according to the manufacturer's instructions with minor modifications. Briefly, oocytes or embryos were lysed by adding $150 \mu \mathrm{l}$ of lysis-binding buffer (100 mmol Tris- $\mathrm{HCl} \mathrm{l}^{-1}, \mathrm{pH} 8.0,500 \mathrm{mmol} \mathrm{LiCl} \mathrm{l}{ }^{-1}, 10 \mathrm{mmol}$ EDTA I $^{-1}, 1 \%(\mathrm{w} / \mathrm{v})$ Lithium dodecysulfate (LiDS), $5 \mathrm{mmol}$ dithithreitol $\mathrm{l}^{-1}$ ), vortexed for $10 \mathrm{~s}$, centrifuged at $12000 \mathrm{~g}$ for $15 \mathrm{~s}$ and incubated at room temperature for $10 \mathrm{~min}$. Prewashed Dynabeads ${ }^{12}$ Oligo $(\mathrm{dT})_{25}(10 \mu \mathrm{l})$ was pipetted into the fluid. After $5 \mathrm{~min}$ incubation at room temperature for binding poly (A) ${ }^{+}$RNAs to oligo (dT) Dynabeads, the beads were separated using a Dynal MPC-E-1 magnetic separator, washed once using $100 \mu \mathrm{l}$ washing buffer 1 (10 mmol Tris- $\mathrm{HCl} 1^{-1}$, $\mathrm{pH} 8.0,0.15 \mathrm{~mol} \mathrm{LiCl} \mathrm{l}^{-1}, 1 \mathrm{mmol}$ EDTA l ${ }^{-1}, 0.1 \%(\mathrm{w} / \mathrm{v})$ LiDS) and three times with $100 \mu \mathrm{l}$ washing buffer $2(10 \mathrm{mmol}$

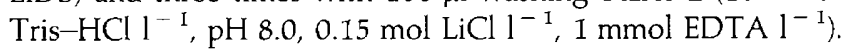
Poly $(A)^{+}$RNAs were then eluted from the beads by 
incubation in $11 \mu \mathrm{l}$ sterile water at $65^{\circ} \mathrm{C}$ for $2 \mathrm{~min}$ and aliquots were used immediately for RT.

As a positive control, total RNA was also extracted from bovine tongue epithelium by a modification of the method of Chomczynski and Sacchi (1987). The scraped epithelial cells were homogenized in solution D (4 mol guanidine thiocyanate $\mathrm{l}^{-1}, 0.5 \%(\mathrm{w} / \mathrm{v})$ sarkosyl, $100 \mathrm{mmol} 2$-mercaptoethanol $\mathrm{l}^{-\mathrm{I}}$, $25 \mathrm{mmol}$ sodium citrate $\mathrm{l}^{-1}, \mathrm{pH} 7.0$ ). Subsequently, $85 \mu \mathrm{l}$ of 2 mol sodium acetate $1^{-1}, \mathrm{pH} 4.0,850 \mu \mathrm{l}$ of phenol (acid, Aqua ${ }^{\mathrm{K}}$-Phenol, Roth), and $170 \mu \mathrm{l}$ chloroform-isoamyl alcohol mixture (49:1) were added to an $850 \mu$ l aliquot of the homogenate, with thorough mixing after the addition of each component. The final suspension was shaken vigorously for $10 \mathrm{~s}$ and cooled on ice for $15 \mathrm{~min}$. Samples were centrifuged at $10000 \mathrm{~g}$ for $20 \mathrm{~min}$ at $4^{\circ} \mathrm{C}$. After centrifugation, the aqueous phase was transferred to a fresh tube, mixed with $1 \mathrm{ml}$ isopropanol, and then held at $-80^{\circ} \mathrm{C}$ for $60 \mathrm{~min}$ to precipitate RNA. The sample was centrifuged again under the same conditions and the resulting RNA pellet was washed twice using $70 \%$ ethanol. After drying at $37^{\circ} \mathrm{C}$, the pellet was dissolved in $100-200 \mu \mathrm{l}$ sterile water and aliquoted in $30 \mu \mathrm{l}$ portions. Contaminating genomic DNA was digested by incubating the samples with $10 \mathrm{iu}$ DNase (Boehringer, Mannheim) for $30 \mathrm{~min}$ at $37^{\circ} \mathrm{C}$. DNase was inactivated by heating samples to $80^{\circ} \mathrm{C}$ for $10 \mathrm{~min}$. Tissue RNA concentration and purity were determined by spectrophotometry. The integrity of the RNA was analysed by ethidium bromide staining after electrophoresis on an agarose (1\%) gel.

\section{Reverse transcription}

Poly $(A)^{+}$RNA isolated from different numbers of oocytes or embryos (20-50) or $200 \mathrm{ng}$ total RNA from tissue (tongue epithelium) was reverse transcribed into cDNA in a total volume of $20 \mu \mathrm{l}$. The reaction mixture consisted of $1 \times \mathrm{RT}$ buffer $\left(50 \mathrm{mmol} \mathrm{KCl} \mathrm{l}^{-1}, 10 \mathrm{mmol}\right.$ Tris- $\mathrm{HCl} \mathrm{l} \mathrm{l}^{-1}, \mathrm{pH} 8.3$, Perkin-Elmer, Vaterstetten), $5 \mathrm{mmol} \mathrm{MgCl}_{2} \mathrm{l}^{-1}, 1 \mathrm{mmol}$ of each dNTP $\mathrm{I}^{-1}$ (Amersham, Brunswick), $2.5 \mu \mathrm{mol}$ random hexamers $\mathrm{I}^{-1}$ (Perkin-Elmer), 20 iu RNase inhibitor (PerkinElmer) and 50 iu murine leukaemia virus (MuLV) reverse transcriptase (Perkin-Elmer). The mixture was overlaid with mineral oil to prevent evaporation. The $\mathrm{RT}$ reaction was carried out at $25^{\circ} \mathrm{C}$ for $10 \mathrm{~min}$, and then at $42^{\circ} \mathrm{C}$ for $1 \mathrm{~h}$ followed by a denaturation step at $99^{\circ} \mathrm{C}$ for $5 \mathrm{~min}$ and flash cooling on ice.

\section{Polymerase chain reaction}

PCR was performed with $\mathrm{CDNA}$ equivalents corresponding to $1-10$ oocytes or embryos or $0.5-5.0 \mathrm{ng}$ tissue RNA in a final volume of $100 \mu \mathrm{l}$ of $1 \times$ PCR buffer $(20 \mathrm{mmol}$ Tris $-\mathrm{HCl}$ $\mathrm{l}^{-1}, \mathrm{pH} 8.4,50 \mathrm{mmol}^{\mathrm{KCl} \mathrm{l}}{ }^{-1}$, Gibco BRL, Eggenstein), $1.5 \mathrm{mmol} \mathrm{MgCl} 21^{-1}, 200 \mu \mathrm{mol}$ of each dNTP $1^{-1}, 1 \mu \mathrm{mol}$ of each sequence specific primer using a PTC-200 thermocycler (MJ Research, Watertown, MA). During hot start, 1 iu Taq DNA polymerase (Gibco) was added at $72^{\circ} \mathrm{C}$. PCR primers (Table 1) were designed from the coding regions of each gene sequence using the OLIGO ${ }^{\mathrm{R}}$-program.

The PCR program used an initial step at $99^{\circ} \mathrm{C}$ for $5 \mathrm{~min}$ and $72^{\circ} \mathrm{C}$ for $2 \mathrm{~min}$ (hot start) followed by 35 cycles of $15 \mathrm{~s}$ at $95^{\circ} \mathrm{C}$ for DNA denaturation, $15 \mathrm{~s}$ at different temperatures for annealing of primers (Table 1 ), and $15 \mathrm{~s}$ at $72^{\circ} \mathrm{C}$ for primer extension. The last cycle was followed by a 5 min extension at $72^{\circ} \mathrm{C}$ and cooling to $4^{\circ} \mathrm{C}$. After addition of $10 \mu \mathrm{l}$ of $10 \times$ load-

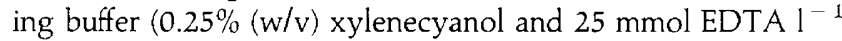
in $50 \%$ glycerin), the RT-PCR products were subjected to electrophoresis on a $2 \%$ agarose gel containing $0.5 \mu \mathrm{g}$ ethidium bromide $\mathrm{ml}^{-1}$ together with a molecular weight marker (pBR322DNA-MspI Digest, New England Biolabs GmbH, Schwalbach) and photographed on an $312 \mathrm{~nm}$ UV transilluminator. As negative controls, tubes were always prepared in which RNA or reverse transcriptase was omitted during the RT reaction. The assays were repeated at least three times with different oocyte or embryo batches and provided consistent results.

The identity of the RT-PCR fragments was confirmed by sequencing the products from each primer pair using an automated DNA sequencing device (DNA sequencer, model 4000L, Li-Cor, Lincoln, NE). The original gel was scanned into a computer. The products of each gene transcript were mounted as one picture using Harvard Graphics ${ }^{\mathrm{R}}$ for Windows, Version 2.0 (Software Publishing Corp., Santa Clara, CA) after digitalization using the $\mathrm{CAM}^{\mathrm{K}}$ program (Cybertech CS-1 Image Documentation System, Berlin, Germany) to demonstrate the temporal mRNA expression pattern from the immature oocyte to the hatched blastocyst.

\section{Results}

Production of bovine embryos in vitro

Oocytes and embryos from 27 IVP runs were used in this study. The rate (ranges) of development (percentage of embryos relative to the total number of oocytes) were as follows: $73-82 \%$ maturation rate, $62-75 \%$ normal fertilization, $53-72 \% 2-4$ cell stages, $44-63 \% 8-16$ cell stages, $33-46 \%$ morulae, $23-32 \%$ blastocysts, $11-22 \%$ hatched blastocysts.

\section{Validity of the RT-PCR assay}

cDNA samples were prepared from pools of embryos to determine the representative pattern of mRNA expression in preimplantation bovine embryos derived from this semidefined culture system yielding high developmental rates (see Brackett and Zuelke, 1993; Trounson et al., 1994). Each reversetranscribed cDNA sample was tested for the absence of contaminating genomic DNA by omitting reverse transcriptase, or for contaminating exogenous RNA or DNA by omitting embryonic RNA during the RT reaction (data not shown). Amplified fragments were never detected in these negative controls. The RT-PCR assay was sensitive enough to detect bovine mRNA from tongue epithelium at levels from 0.5 to $5.0 \mathrm{ng}$ (data not shown). This corresponds well to the total amount of RNA (2.4 ng) found in the bovine oocyte (Bilodeau-Goeseels and Schultz, 1997a). Analyses were repeated with increasing numbers of embryos or using specific priming of the RT reaction, as well as increasing the number of PCR cycles, to verify that the failure to detect a transcript was not attributed to sensitivity problems (data not shown). The 
Table 1. Primers used for polymerase chain reaction

\begin{tabular}{|c|c|c|c|c|}
\hline Genes & Primer sequences and positions & $\begin{array}{c}\text { Annealing } \\
\text { temperature }\left({ }^{\circ} \mathrm{C}\right)\end{array}$ & $\begin{array}{l}\text { Fragment size } \\
\text { (bp) }\end{array}$ & $\begin{array}{l}\text { Sequence references } \\
\text { [EMBL accession no.] }\end{array}$ \\
\hline $\begin{array}{l}\text { Connexin } 43 \\
\text { (Cx43) }\end{array}$ & $\begin{array}{l}\text { 5'primer }(736-765)= \\
\text { GGGAAAGAGCGATCCTTACCACACTACCAC } \\
\text { 3'primer }(1222-1251)= \\
\text { CCACCTCCAATGAAACAAAATGAACACCTA }\end{array}$ & 60 & 516 & $\begin{array}{c}\text { Lash et al. (1990) } \\
\quad \text { [J05535] }\end{array}$ \\
\hline $\begin{array}{l}\text { Desmoglein } 1 \\
\text { (Dg 1) }\end{array}$ & $\begin{array}{l}\text { 5'primer }(836-850)= \\
\text { GCAGATGGTATGTCAGCAGAGTGTG } \\
\text { 3'primer }(1596-1620)= \\
\text { GAAGTAAGGCCATATGCAGAGGTAG }\end{array}$ & 53.5 & 785 & $\begin{array}{l}\text { Koch et al. (1991) } \\
\quad[X 58466]\end{array}$ \\
\hline $\begin{array}{l}\text { Desmocollin I } \\
\text { (Dc I) }\end{array}$ & $\begin{array}{l}\text { 5'primer }(2412-2436)= \\
\text { GGTGTTGGGTTCTGTATTGTTGTTA } \\
\text { 3'primer }(2875-2899)= \\
\text { GTAGTCTTCGCAGAGCTTGTGTTCC }\end{array}$ & 55 & $\begin{array}{c}488 / 441 \\
\text { (insertion of } \\
46 \text { bp, 2803-2848) }\end{array}$ & $\begin{array}{l}\text { Collins et al. (1991) } \\
\text { [X56966] }\end{array}$ \\
\hline $\begin{array}{l}\text { Desmocollin II } \\
\text { (Dc II) }\end{array}$ & $\begin{array}{l}\text { 5'primer }(2085-2109)= \\
\text { CTCCTGGCGATGACAAAGTGTATTC } \\
\text { 3'primer }(2503-2527)= \\
\text { GCCGATCCTCTTCCTTCGTAGTTAT }\end{array}$ & 57 & $\begin{array}{c}443 / 397 \\
\text { (insertion of } \\
46 \mathrm{bp}, 2396-2441 \text { ) }\end{array}$ & $\begin{array}{l}\text { Koch et al. (1992) } \\
\text { [M81190] }\end{array}$ \\
\hline $\begin{array}{l}\text { Desmocollin III } \\
\text { (Dc III) }\end{array}$ & $\begin{array}{l}\text { 5'primer }(2088-2117)= \\
\text { GCCATACTTCTGGGCATAGCACTACTTTTC } \\
\text { 3'primer }(2555-2584)= \\
\text { GTGATGGCATGTGCTCTTCGTCCTGATTAC }\end{array}$ & 57 & $\begin{array}{c}497 / 454 \\
\text { (insertion of } \\
43 \text { bp; } 2499-2541 \text { ) }\end{array}$ & $\begin{array}{l}\text { Yue et al. (1995) } \\
\text { [L33774] }\end{array}$ \\
\hline $\begin{array}{l}\text { Plakophilin } \\
\text { (Plako) }\end{array}$ & $\begin{array}{l}\text { 5'primer }(1337-1361)= \\
\text { CCCGTGGACCCCGAGGTCTTCTTCA } \\
\text { 3'primer }(1580-1604)= \\
\text { CGGTGTAGGCGTTGCGGGCGTTGTA }\end{array}$ & 64 & 268 & $\begin{array}{l}\text { Heid et al. (1994) } \\
\text { [Z37975] }\end{array}$ \\
\hline $\begin{array}{l}\text { Glucosetransporter I } \\
\text { (Glut-1) }\end{array}$ & $\begin{array}{l}\text { 5'primer }(1609-1638)= \\
\text { AGGAGCTGTTCCACCCCCTGGGAGCTGACT } \\
\text { 3'primer }(1906-1935)= \\
\text { TGTGGGTGAAGGAGACTCTGGCTGATAAAA }\end{array}$ & 59 & 327 & $\begin{array}{c}\text { Boado and Pardridge } \\
\text { (1991) } \\
\text { [M60448] }\end{array}$ \\
\hline $\begin{array}{l}\text { Poly(A)polymerase } \\
\text { (PolyA) }\end{array}$ & $\begin{array}{l}5^{\prime} \text { primer }(886-915)= \\
\text { GTTTCCTCGGTGGTGTTTCCTGGGCTATGC } \\
3^{\prime} \text { primer }(1108-1137)= \\
\text { TGGAGTTCTGTTGTGGGTATGCTGGTGTAA }\end{array}$ & 57 & 252 & $\begin{array}{c}\text { Raabe et al. (1991) } \\
{[\text { X63436] }}\end{array}$ \\
\hline $\begin{array}{l}\text { Heat shock protein } 70.1 \\
\text { (HSP) }\end{array}$ & $\begin{array}{l}\text { 5'primer }(1861-1890)= \\
\text { AAGGTGCTGGACAAGTGCCAGGAGGTGATT } \\
3^{\prime} \text { primer }(2319-2348)= \\
\text { ACTTGGAAGTAAACAGAAACGGGTGAAAAA }\end{array}$ & 59 & 488 & $\begin{array}{l}\text { DeLuca-Flaherty and } \\
\text { McKay (1990) } \\
\text { [X53827] }\end{array}$ \\
\hline $\begin{array}{l}\text { Trophoblast protein } \\
\text { (TP) }\end{array}$ & $\begin{array}{l}5^{\prime} \text { primer }(420-423)= \\
\text { GCTATCTCTGTGCTCCATGAGATG } \\
3^{\prime} \text { primer }(755-778)= \\
\text { AGTGAGTTCAGATCTCCACCCATC }\end{array}$ & 57 & 359 & $\begin{array}{c}\text { Imakawa ef al. (1989) } \\
\text { [G163764] }\end{array}$ \\
\hline
\end{tabular}

detection of PolyA mRNA from pooled embryos demonstrated that RT had been achieved, indicating the presence of intact RNA. Only good quality embryos were selected for use in this study. Lequarre et al. (1997) have suggested that embryo quality and mRNA contents are correlated.

\section{RNA expression of developmentally important genes in} preimplantation bovine embryos

Transcripts for $\mathrm{Cx} 43$ were detected up to the morula stage in IVP oocytes or embryos by the fragment of $516 \mathrm{bp}$. Therefore, the origin could be maternal and embryonic. Morulae and blastocysts produced in vivo showed transcription of the $\mathrm{C} x 43$ gene (data not shown). Transcripts of Dc II and Dc III were detectable from the 2-4 cell stage onwards in IVP embryos, indicated by the predicted sizes of the fragments, $443 / 397 \mathrm{bp}$ and $497 / 454 \mathrm{bp}$, suggesting an embryonic origin of both splice variants. The transcripts were also found in in vivo stages. mRNA encoding Plako was detected in immature and in vitro matured oocytes and zygotes generated in vitro. The transcript could not be amplified from IVP 2-4 and 8-16 cell embryos. Transcription resumed at the morula stage, suggesting the temporal separation of maternal and embryonic expression. Morulae and blastocysts generated in vivo transcribed the gene as shown by the fragment of the expected size of $268 \mathrm{bp}$. No transcripts were found for $\mathrm{Dg} I$ and Dc I at any stages (data not shown). However, fragments with the expected sizes were detected using bovine tongue epithelium total RNA samples (785 bp and $488 / 44 \mathrm{I} \mathrm{bp}$, respectively). 

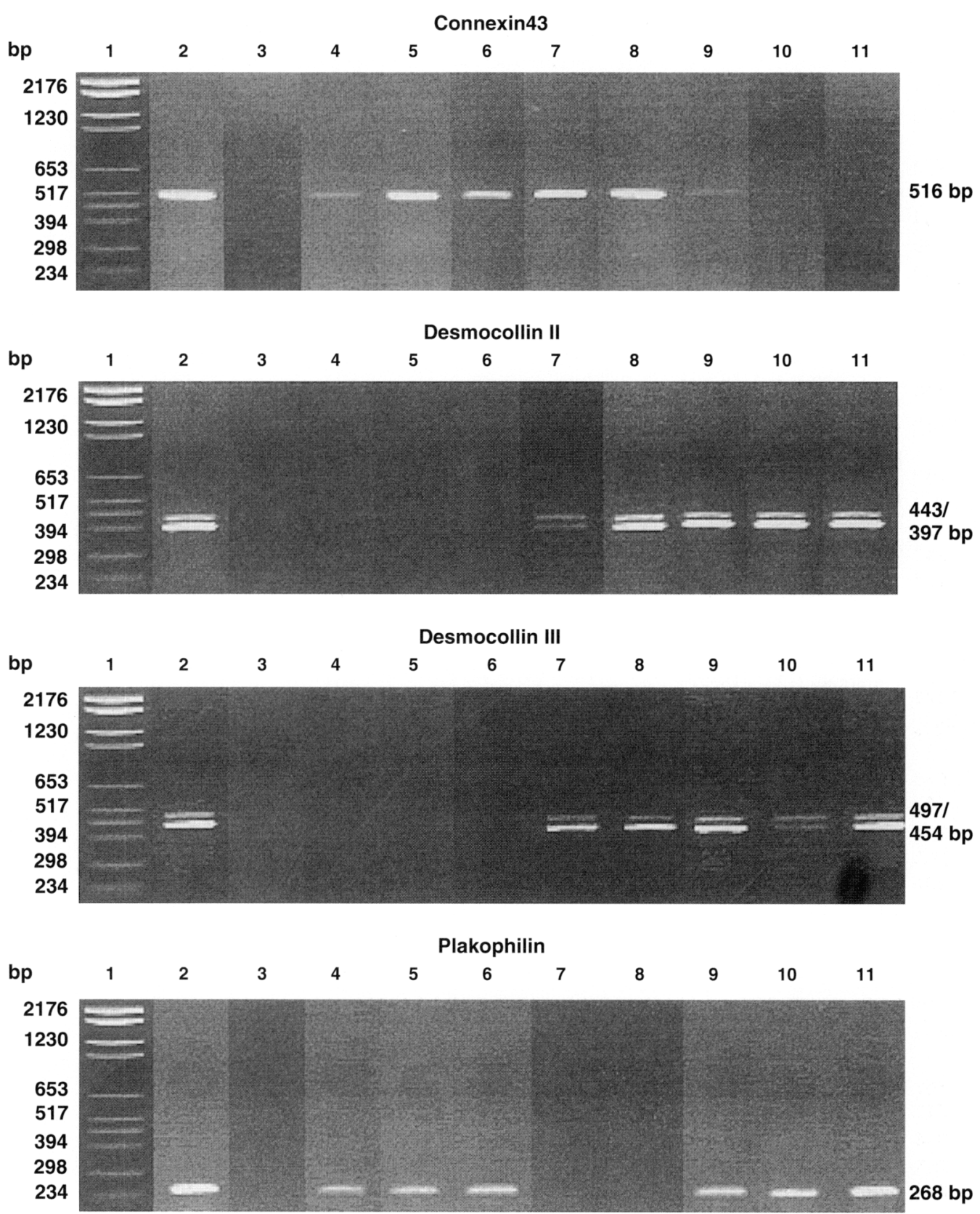

Fig. 1(a).

Transcripts encoding Glut-1, PolyA and the HSP were detectable throughout bovine preimplantation development in witro as indicated by amplicons with the expected sizes of 488 bp, 252 bp and 327 bp, respectively, suggesting that these transcripts are of both maternal and embryonic origin. These products were also identified in bovine morulae and blastocysts produced in vivo. Trophoblast protein was transcribed at the blastocyst stage in IVP embryos, indicating an embryonic origin. The 359 bp fragment was not detectable in morulae produced in wow, whereas it was found in blastocysts produced in vivo. The transcriptional pattern of the genes with detectable fragments throughout bovine preimplantation development in vitro is shown (Fig. 1).
The results of the transcription pattern in all preimplantation stages of bovine oocytes or embryos generated in vitro (Table 2) and of morulae and blastocysts derived in vivo (Table 3) are summarized. RT-PCR products were sequenced to ensure the specificity of PCR amplification. The obtained sequences possessed identical nucleotide sequences to the published bovine DNA sequence data.

\section{Discussion}

In the present study, the effects of a semi-defined culture system on the temporal mRNA expression pattern of ten 


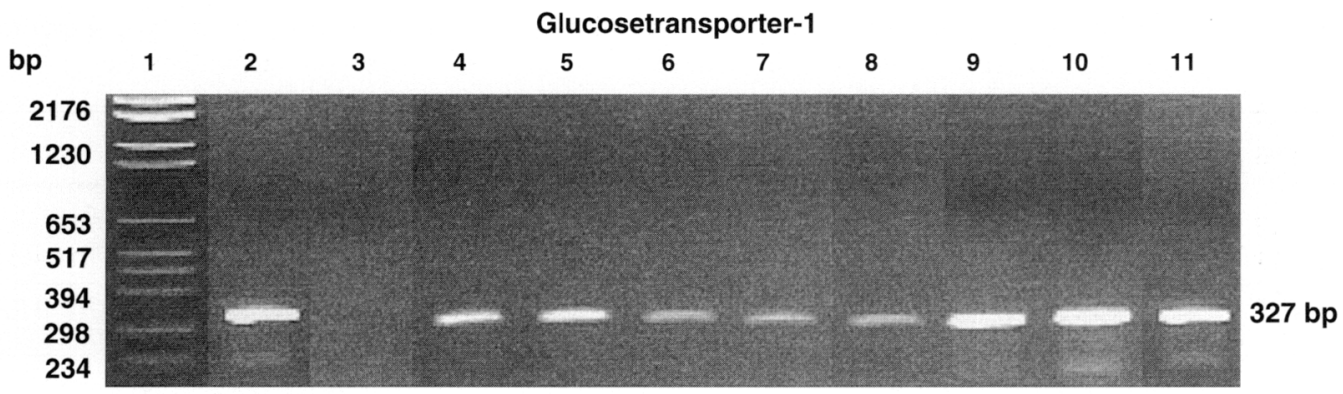

Poly(A)polymerase
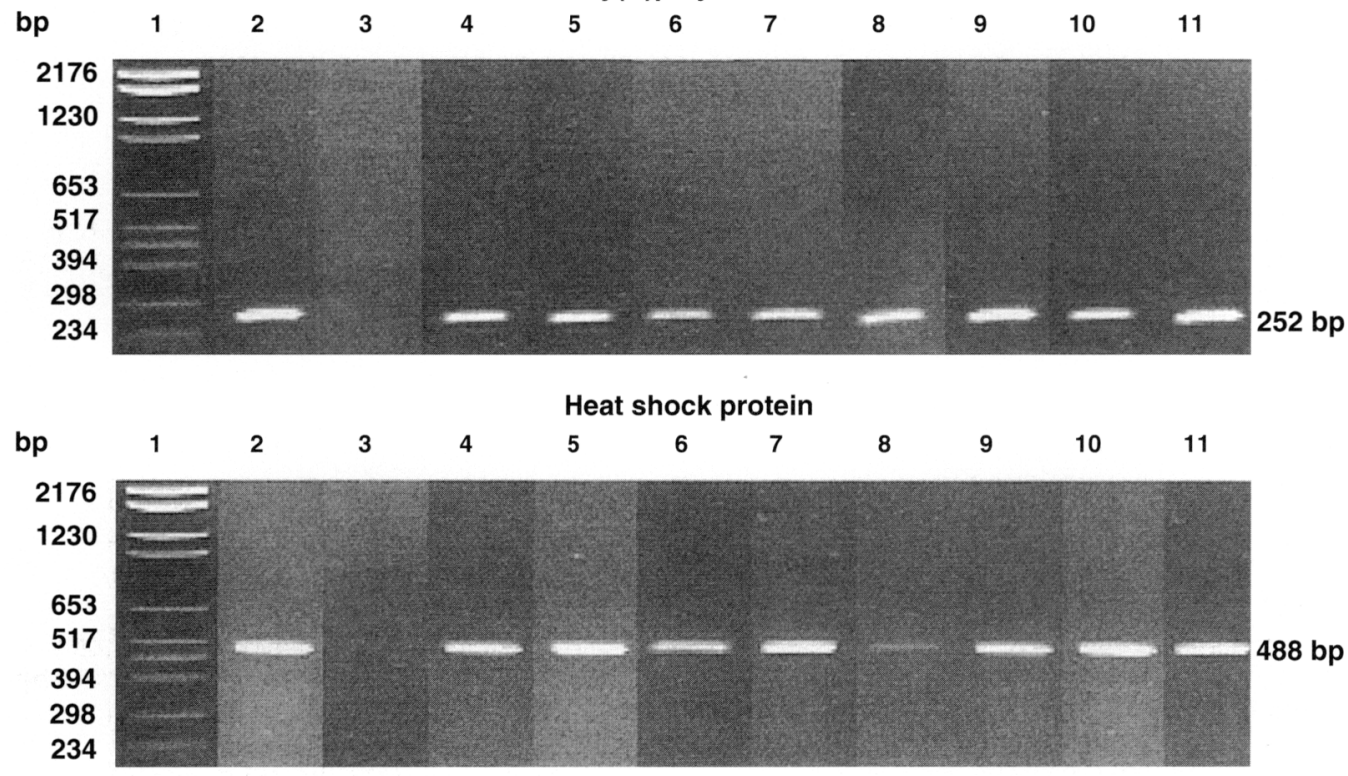

Trophoblastprotein

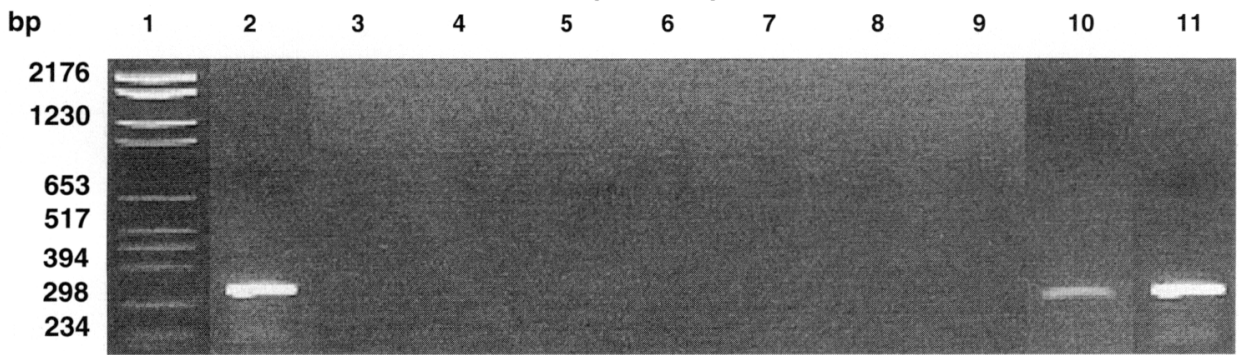

359 bp

Fig. 1(b).

Fig. 1. Transcripts (reverse transcriptase-polymerase chain reaction (RT-PCR) products) of developmentally important genes in preimplantation bovine oocytes or embryos generated in iifro. Each lane represents the RT-PCR product derived from Poly $(A)^{+}$RNA from the equivalent of ten (oocytes $-2-4$ cell embryos), five (8-16 cell embryos), two (morulae) or one (blastocysts and hatched blastocysts) oocytes or embryos. Lane I, molecular weight marker (to verify the size of the amplified fragments); lane 2, positive control (bovine tongue); lane 3, negative controls omitting RNA; lane 4, immature oocytes; lane 5, matured oocytes; lane 6, zygotes; lane 7, 2-4 cell embryos; lane 8, 8-16 cell embryos; lane 9, morulae; lane 10, blastocysts; lane 11, hatched blastocysts. Each figure is a montage of individual gels run for each group of oocytes or embryos showing the presence or absence of fragments of the expected size(s) for each gene transcript. In the case of Dc I (data not shown). Dc II and Dc III, both splice variants of the gene transcript were detectable.

developmentally important genes has been analysed in bovine oocytes and embryos produced in vitro using RT-PCR. The transcriptional pattern of the transferable stage morulae and blastocysts produced under semi-defined culture conditions was compared with that of their in vivo counterparts. The transcripts determined may be of maternal (oocyte: $2-4$ cell 
Table 2. Transcription of developmentally important genes in preimplantation bovine embryos generated in vitro

\begin{tabular}{|c|c|c|c|c|c|c|c|c|}
\hline \multirow[b]{3}{*}{ Genes } & \multicolumn{8}{|c|}{ Developmental stages examined } \\
\hline & \multicolumn{4}{|c|}{$\begin{array}{l}\text { Suggested maternal } \\
\text { transcription only }\end{array}$} & \multicolumn{4}{|c|}{$\begin{array}{l}\text { Suggested maternal and } \\
\text { embryonic transcription }\end{array}$} \\
\hline & 10 & $\mathrm{MO}$ & Z & $2-4$ & $8-16$ & $\mathrm{M}$ & B & $\mathrm{HB}$ \\
\hline $\begin{array}{l}\text { Connexin } 43 \\
(\mathrm{Cx} 43)\end{array}$ & + & + & + & + & + & + & - & - \\
\hline $\begin{array}{l}\text { Desmoglein } 1 \\
(\mathrm{Dg} 1)\end{array}$ & - & - & - & - & - & - & - & - \\
\hline $\begin{array}{l}\text { Desmocollin I } \\
\text { (Dc I) }\end{array}$ & - & - & - & - & - & - & - & - \\
\hline $\begin{array}{l}\text { Desmocollin II } \\
\text { (Dc II) }\end{array}$ & - & - & - & + & + & + & + & + \\
\hline $\begin{array}{l}\text { Desmocollin III } \\
\text { (Dc III) }\end{array}$ & - & - & - & + & + & + & + & + \\
\hline $\begin{array}{l}\text { Plakophilin } \\
\text { (Plako) }\end{array}$ & + & + & + & - & - & + & + & + \\
\hline $\begin{array}{l}\text { Glucosetransporter } 1 \\
\text { (Glut-1) }\end{array}$ & + & + & + & + & + & + & + & + \\
\hline $\begin{array}{l}\text { Poly }(A) \text { polymerase } \\
\text { (PolyA) }\end{array}$ & + & + & + & + & + & + & + & + \\
\hline $\begin{array}{l}\text { Heat shock protein } 70.1 \\
\text { (HSP) }\end{array}$ & + & + & + & + & + & + & + & + \\
\hline $\begin{array}{l}\text { Trophoblast protein } \\
\text { (TP) }\end{array}$ & - & - & - & - & - & - & + & + \\
\hline
\end{tabular}

+ , transcripts detectable; - , transcripts not detectable (representing consistent results from three replicates, each representing 1-10 oocytes/embryos).

IO. immature oocytes; MO, matured oocytes; Z, zygotes; 2-4, 2-4 cell embryos; 8-16, 8-16 cell embryos; M, morulae; B, blastocysts, HB, hatched blastocysts.

Table 3. Transcription of developmentally important genes in in vivo derived bovine morulae and blastocysts

\begin{tabular}{lccccccccccc}
\hline & Cx43 & Dg I & Dc I & Dc II & Dc III & Plako & Glut-1 & PolyA & HSP & TP \\
\hline Morulae & + & - & - & + & + & + & + & + & + & - \\
Blastocysts & + & - & - & + & + & + & + & + & + & + \\
\hline
\end{tabular}

+ , transcripts detectable; - , transcripts not detectable (representing consistent results from three replicates, each representing 2 morulae or 1 blastocyst).

Cx43, connexin43; Dg 1, desmoglein 1; DC, desmocollin; Plako, plakophilin; Glut-1, glucosetransporter 1; HSP, heat shock protein 70.1; TP, trophoblast protein.

stage) origin only or may be of both maternal and embryonic (beginning at the 8-16 cell stage) origin. These transcripts are involved in compaction and cavitation (Cx43, Dg 1, Dc I, II, III, Plako), metabolism (Glut-1), RNA processing (PolyA), stress (HSP), and maternal recognition of pregnancy (TP).

During murine preimplantation development, functional gap junctions are first observed at compaction at the eight-cell stage (Lo and Gilula, 1979; Goodall and Johnson, 1984) and mRNA encoding $\mathrm{Cx} 43$ and $\mathrm{Cx} 43$ protein are detected from the four-cell stage onwards (Nishi et al., 1991). The rate limiting step of gap junction coupling is regulated by the insertion of nascent subunits into plasma membranes downstream of tran- scription and translation (De Sousa et al., 1993). Expression of $\mathrm{C} \times 43$ before the morula stage could indicate the presence of precursor pools (McLachlin et al., 1983; Valdimarsson et al., 1991) and, thus, the preparatory step for compaction and blastulation. No gap junction coupling was visible in bovine blastocysts produced in vitro (Prather and First, 1993), and the Cx43 gene was transcribed up to the morula stage in IVP bovine embryos, whereas the transcript was found in blastocysts produced in vivo (Wrenzycki et al., 1996). In the present study, similar culture conditions were used as in the previous study with two exceptions. The semen used for IVF stemmed from a different bull and maturation and culture media were 
supplemented with BSA instead of oestrus cow serum (OCS). Serum was substituted by BSA because serum has been attributed with pertubations in embryo morphology, metabolism, ultrastructure and postimplantation development (Dorland et al., 1994; Gardner, 1994; Thompson et al., 1995). Since identical transcription patterns were detected for $\mathrm{Cx} 43$ with both BSA and serum, it was concluded that neither serum nor BSA nor the bull affect transcription of this gene. Further studies are needed to investigate the effects of the lack of $\mathrm{Cx} 43$ expression in bovine embryos derived in vitro on developmental capacity in vivo. In rat ovaries, it has been shown that gonadotrophins regulate expression of mRNA encoding $\mathrm{Cx} 43$ and $\mathrm{C} \times 43$ protein (Granot and Dekel, 1997). In addition, a similiar expression pattern was found for the GCS (glutamylcysteine synthetase) gene in IVP bovine embryos (Harvey et al., 1995).

Desmosome formation is correlated with the onset of blastocoel formation in mouse embryos (Fleming et al., 1991; Collins $e t$ al., 1995). Three types of bovine desmocollins have been described (Legan et al., 1994), each being the product of a different gene and being expressed as a pair of alternatively spliced forms ( $a$ and $b$ ). The $b$ form possesses an additional $46 \mathrm{bp}$ in Dc I and II (43 bp in the case of Dc III) exon (Legan et al., 1994). The $\mathrm{a}$ and $\mathrm{b}$ forms of Dc II are transcribed in mouse oocytes and cleavage stages up to the early eight-cell stage, are never detected in compact eight-cell embryos, and appear again from the 16-cell stage onwards (Collins et al., 1995). In mouse blastocysts, mRNA encoding Dc II is localized within the trophectoderm. After isolation and culture of ICMs from early mouse blastocysts, the outer cells start to form a new trophectodermal layer indicated by an increase in Dc II transcription (Collins et al., 1995). The present data show for the first time that the transcripts of Dc II and Dc III in bovine embryos are of embryonic origin and both splice variants are detectable. In contrast, Dc I and Dg I were not transcribed throughout bovine preimplantation development. The transcriptional pattern of Plako suggests that the transcripts are first of maternal and subsequently of embryonic origin. These results indicate that Dc II, Dc III and Plako are the first components of desmosomes expressed during bovine preimplantation development.

Glucose was found to be detrimental to bovine embryos in vitro up to the morula stage (Takahashi and First, 1992). During in vitro development from the morula onwards, glucose is the preferred energy substrate (Rieger $e$ al., 1992a, b), as it is in embryos in vivo (Javed and Wright, 1991). Glut-1 was found to be distributed in the trophectoderm and inner cell mass cells of mouse embryos, while Glut-2 was restricted to the inner trophectodermal membranes (Aghayan et al., 1992). The present data demonstrate that Glut-1 is transcribed throughout preimplantation bovine development, suggesting that the transcript is of maternal and embryonic origin. Glut- 1 is expressed in a similar pattern in mouse embryos to that in bovine embryos, whereas Glut-2 is expressed from the eight-cell stage onwards in the mouse embryo (Hogan et al., 1991; Aghayan et al., 1992). Glut- 1 acts as a regulatable transporter in mouse blastocysts, responsive to IGF-I and insulin, and mediated by the IGF-I receptor (Pantaleon and Kaye, 1996). IGF-I was found to have a beneficial effect on the developmental capacity of bovine embryos (Herrler et al., 1992). Bovine embryos pro- duced in vitro transcribe the IGF-I receptor throughout preimplantation development (Watson et al., 1992). These findings support the hypothesis that the positive effect of IGF-I is attributed to an enhanced glucose uptake by these embryos. Furthermore, Glut-1 transcription and glucose uptake are known to be affected by in vitro culture conditions. Concentrations of mRNA encoding Glut-1 and glucose incorporation were significantly reduced in mouse blastocysts produced in vitro compared with blastocysts grown in vivo (Morita et al., 1994). In addition, the metabolism of IVP embryos was increased compared with that of the embryos in vivo, indicating the involvement of several genes in the regulation of embryo metabolism (Khurana and Niemann, 1992).

Polyadenylation regulates gene expression via posttranscriptional modulation, translation or stability of mRNA. Extension of a pre-existing short poly $(A)$ tail is associated with mRNA activation, and deadenylation is correlated with cessation of translation (Paynton et al., 1988). Maternal mRNAs gain or lose their poly(A) tail in the cytoplasm at specific timepoints during development (Bachvarova et al., 1985; Paynton and Bachvarova, 1994). The present study demonstrates that the gene encoding this protein is transcribed throughout development in preimplantation bovine embryos. A transient polyadenylation of a maternal mRNA was found after fertilization of mouse oocytes (Temeles and Schultz, 1997). Several mRNAs, for example those encoding tissue plasminogen activator (tPA) and hypoxanthine phosphoribosyltransferase (HPRT), are known to be polyadenylated during oocyte maturation (Huarte et al., 1987; Vassalli et al., 1989; Sallés and Strickland, 1995). Brevini-Gandolfi et al. (1997) have demonstrated that the developmental capacity of bovine oocytes is correlated with the length of the poly $(\mathrm{A})$ tail of epidermal growth factor and Oct4 transcripts. The adenylation status of most of the specific bovine mRNAs remains unknown.

Maternal exposure to increased temperatures during ovulation and early embryonic development is correlated with embryonic death (Ealy et al., 1993; Edwards and Hansen, 1996, 1997). The sensitivity of maturing oocytes and early embryos to increased temperature has been attributed to the lack of an appropriate mechanism that confers heat resistance. Molecules of the HSP70 family were found to provide thermoprotection by refolding damaged proteins and protecting rRNA (Duncan and Hershey, 1989; Nover and Scharf, 1991). The data from the present study demonstrate that transcripts encoded by the HSP70.1 gene are detectable throughout bovine preimplantation development, suggesting a stage-specific mechanism of bovine oocytes and embryos to heat shock. In oocytes, heat shock altered the development to blastocysts, whereas morulae were not affected (Edwards and Hansen, 1996, 1997). Transcription of the mouse HSP70.1 gene is enhanced at the onset of zygotic genome activation and the amount of transcription was found to be modulated by in vitro culture conditions. The transcriptional activity of HSP70.1 was 15 times higher in mouse embryos generated in vitro than in the embryos in vivo (Christians et al., 1995). Furthermore, timing of induced thermotolerance (a phenomenon whereby exposure to a mild heat shock confers thermotolerance to a subsequent more severe heat shock) differed for mouse embryos that developed in culture as compared with the embryos in vivo (Ealy and Hansen, 
1994). There is some evidence that heat shock-induced synthesis of HSP precedes induction of thermotolerance (Edwards et al., 1995), suggesting similar factors are involved in thermotolerance (Edwards and Hansen, 1997). It has also been proposed that HSP7O is switched on by free oxygen radicals that are correlated with embryonic arrest and cell death (Johnson and Nasr-Esfahani, 1994). During heat shock, cellular damage is caused by a variety of factors and a single thermoprotectant is probably unable to protect cells from damaging effects (Aréchiga et al., 1995). On the basis of these findings, HSP70.I could prove a useful tool to indicate stress caused by suboptimal culture conditions.

Trophoblast protein is secreted by the trophectoderm of bovine conceptuses between days 15 and 24 of gestation (Bartol et al., 1985). This antiluteolytic signal is primarily responsible for inhibiting uterine production of luteolytic concentrations of $\mathrm{PGF}_{2 \alpha}$ (Bazer et al., 1991). The present data confirm the report of Watson et al. (1992) that mRNA encoding TP found in bovine blastocysts and hatched blastocysts indicates an embryonic origin.

Among all the transcripts analysed, the only difference between morulae and blastocysts generated in vitro and in vivo was observed for $\mathrm{Cx} 43$, confirming our findings for bovine embryos cultured in serum-enriched medium (Wrenzycki et al., 1996). This suggests that expression of the Cx43 gene is not affected by either serum or BSA and that this gene could be a suitably sensitive candidate to be included in a set of appropriate marker genes indicating the quality of an IVP system for bovine embryos. It has been shown that culture conditions alter gene expression in mouse preimplantation embryos (Anbari and Schultz, 1993; Vernet et al., 1993; Ho et al., 1994, 1995; Shim et al., 1996). Furthermore, in vitro culture has profound effects on post-implantation development and is thought to be associated with increased duration of gestation and mortality as indicated by abnormally large fetuses and offspring after transfer of IVP embryos (Kruip and denDaas, 1997). Therefore, further investigations are needed to improve in vitro culture conditions of preimplantation embryos. The use of a determined set of genes covering a broad range of physiological systems in the embryos to assess the quality of the in vitro production system will be instrumental in improving the quality of the embryos produced. Morphological criteria are not sufficient to assess embryo quality in an objective manner because IVP bovine embryos are more difficult to evaluate than their in vivo counterparts (Farin et al., 1995). The quantitative pattern of gene transcription in bovine preimplantation embryos generated in vivo and in vitro are currently being investigated using a semiquantitative RT-PCR assay to gain insight into the regulation of transcription.

In conclusion, for the first time the ontogenetic pattern of the transcription of a broad set of developmentally important genes has been demonstrated in preimplantation bovine embryos generated in a semi-defined in vitro culture system. The difference between in vitro versus in vivo blastocysts found for the $\mathrm{C} \times 33$ gene is probably caused by the extended in vitro culture of bovine embryos. Therefore, the composition of an optimized culture system for preimplantation embryos is of critical importance for both commercial applications and basic studies.
The authors are grateful to E. Lemme and K-G. Hadeler for their skilled technical assistance. This research was supported by grant $\mathrm{Ni}$ 256/12-1 from the Deutsche Forschungsgemeinschaft (DFG).

\section{References}

Aghayan M, Rao LV, Smith RM, Jarett L, Charron MJ, Thorens B and Heyner S (1992) Developmental expression and cellular localization of glucose transporter molecules during mouse preimplantation development Development 115 305-312

Anbari K and Schultz RM (1993) Effect of sodium and betaine in culture media on development and relative rates of protein synthesis in preimplantation mouse embryos Molecular Reproduction and Development 35 24-28

Aréchiga CF, Ealy AD and Hansen PJ (1995) Evidence that glutathione is involved in thermotolerance of preimplantation murine embryos Biology of Reproduction 52 1296-1301

Bachvarova RF (1992) Maternal tail of poly(A): the long and the short of it Cell $69895-897$

Bachvarova R, Deleon V, Johnson A, Kaplan G and Paynton BV (1985) Changes in total RNA, polyadenylated RNA and actin mRNA during meiotic maturation of mouse embryos Developmental Biology 108 325-33I

Bartol FF, Roberts RM, Bazer FW, Lewis GS, Godkin JD and Thatcher WW (1985) Characterization of proteins produced in vitro by peri-attachment bovine conceptuses Biology of Reproduction $32681-694$

Bavister BD (1995) Culture of preimplantation embryos: facts and artifacts Human Reproduction $191-148$

Bazer FW, Thatcher WW, Hansen PJ, Mirando MA, Ott TL and Plante C (1991) Physiological mechanisms of pregnancy recognition in ruminants Journal of Reproduction and Fertility Supplement 43 39-47

Betts DH, MacPhee DJ, Kidder GM and Watson AJ (1997) Ouabain sensitivity and expression of $\mathrm{Na} / \mathrm{K}$-ATPase $\alpha$ - and $\beta$-subunit isoform genes during bovine early development Molecular Reproduction and Development 46114 126

Bevilacqua A, Loch-Caruso R and Erickson RP (1989) Abnormal development and dye coupling produced by antisense RNA to gap junction protein in mouse preimplantation embryos Proceedings of the National Academy of Sciences USA 86 5444-5448

Bilodeau-Goeseels S and Schultz GA (1997a) Changes in ribosomal ribonucleic acid content within in vitro-produced bovine embryos Biology of Reproduction $56 \quad 1323-1329$

Bilodeau-Goeseels S and Schultz GA (1997b) Changes in the relative abundance of various house keeping gene transcripts in in vitro produced early bovine embryos Molecular Reproduction and Development 47 413-420

Boado RJ and Pardridge WM (1991) Molecular cloning of the bovine bloodbrain barrier glucose transporter CDNA and demonstration of phylogenetic conservation of the 5' untranslated region Molecular Cell and Neuroscience 1 $224-232$

Brackett BG and Zuelke KA (1993) Analysis of factors involved in the in vitro production of bovine embryos Theriogenology 39 43-64

Brevini-Gandolfi TAL, Cillo F, Modina S and Gandolfi F (1997) Defective developmental capacity of bovine oocytes is accompanied by a shorter poly(A) tail of maternal transcripts Journal of Reproduction and Fertility Abstract Series 19 41-42

Buxton RS, Cowin P, Franke WW, Garrod DR, Green KJ, King IA, Koch PJ, Magee AI, Rees DR, Stanley JR and Steinberg MS (1993) Nomenclature of the desmosomal cadherins Journal of Cell Biology 121 481-483

Camous S, Kopecny V and Flechon JE (1986) Autoradiographic detection of the earliest stage ${ }^{3} \mathrm{H}$-uridine incorporation in the cow embryo Biology of the $\mathrm{Cell}$ 58 195-200

Chomczynski P and Sacchi N (1987) Single-step method of RNA isolation by acid guanidinium thiocyanate-phenol-chloroform extraction Analytical Biochemistry 162 156-159

Christians E, Campion E, Thompson EM and Renard J-P. (1995) Expression of the HSP 70.1 gene, a landmark if early zygotic activity in the mouse embryo is restricted to the first burst of transcription Development 121 113-122

Collins JE, Legan PK, Kenny TP, Macgarvie J, Holton JL and Garrod DR (1991) Cloning and sequence analysis of desmosomal glycoproteins 2 and 3 (desmocollins); cadherin-like desmosomal adhesion molecules with heterogenous cytoplasmic domains EMBL GenBank X56966

Collins JE, Lorimer JE, Garrod DR, Pidsley SC, Buxton RS and Fleming TP (1995) Regulation of desmocollin transcription in mouse preimplantation embryos Development 121 743-752 
Davis W, Jr, De Sousa PA and Schultz RM (1996) Transient expression of translation initiation factor eIF-4C during the 2-cell stage of the preimplantation mouse embryo: identification by mRNA differential display and the role of DNA replication in zygotic gene activation Developmental Biology 174 190-201

DeLuca-Flaherty C and McKay DB (1990) Nucleotide sequence of the CDNA of a bovine 70 kilodalton heat shock cognate protein Nucleic Acids Research 18 5569

De Sousa PA, Valdimarsson G, Nicolson BJ and Kidder GM (1993) Connexin trafficking and the control of gap junction assembly in mouse preimplantation embryos Development 117 1355-1367

Dorland M, Gardner DK and Trounson AO (1994) Serum in synthetic oviduct fluid causes mitochondrial degeneration in ovine embryos Journal of Reproduction and Fertility Abstract Series 13 Abstract 70

Duncan RF and Hershey JWB (1989) Protein synthesis and protein phosphorylation during heat stress, recovery, and adaptation journal of Cell Biology 109 1467-1481

Ealy AD and Hansen PJ (1994) Induced thermotolerance during early development of murine and bovine embryos Journal of Cellular Physiology 160 $463-468$

Ealy AD, Drost M and Hansen PJ (1993) Developmental chances in embryonic resistance to adverse effects of maternal heat stress in cows Journal of Dairy Science 76 2899-2905

Eckert J and Niemann H (1995) In vitro maturation, fertilization and culture to blastocysts of bovine oocytes in protein-free media Theriogenology 43 1211-1225

Edwards JL and Hansen PJ (1996) Elevated temperature increases heat shock protein 70 synthesis in bovine two-cell embryos and compromises function of maturing oocytes Biology of Reproduction 55 340-346

Edwards JL and Hansen PJ (1997) Differential responses of bovine oocytes and preimplantation embryos to heat shock Molecular Reproduction and Development $46 \quad 138-145$

Edwards JL, Ealy AD and Hansen PJ (1995) Regulation of heat shock protein 70 synthesis by heat shock in the preimplantation murine embryo and its relationship to induced thermotolerance Theriogenology 44 329-337

Farin PW, Britt SH, Shaw DW and Slenning BD (1995) Agreement among evaluators of bovine embryos produced in vivo or in vitro. Theriogenology 44 339-349

Fleming TP, Garrod DR and Elsmore AJ (1991) Desmosome biogenesis in the mouse preimplantation embryo Development 112 527-539

Fleming JV, Fontanier N, Harries DN and Rees WD (1997) The growth arrest genes gas5, gas6, and CHOP-10 (gadd153) are expressed in the mouse preimplantation embryo Molecular Reproduction and Development 48 310-316

Gardner DK (1994) Mammalian embryo culture in the absence of serum or somatic cell support Cell Biology International 18 1163-1179

Gardner DK and Kaye PL (1995) Characterization of glucose transport in preimplantation mouse embryos Reproduction Fertility and Development 7 $41-50$

Gardner DK and Leese HJ (1988) The role of glucose and pyruvate transport in regulating nutrient utilization by preimplantation embryos Development 104 423-429

Garrod DR (1993) Desmosomes and hemidesmosomes Current Opinion of Cell Biology 5 30-40

Goodall H and Johnson MH (1984) The nature of intercellular coupling within the preimplantation mouse embryo Journal of Embryology and Experimental Morphology $7953-76$

Granot I and Dekel N (1997) Developmental expression and regulation of the gap junction protein and transcript in rat ovaries Molecular Reproduction and Development 47 231-239

Greve T, Callesen H, Hyttel P and Avery B (1994) From oocyte to calf: in vivo and in vitro. In Animal Production and Biotechnology pp 71-97 Eds GF Greppi and $G$ Enne. Elsevier Biofutur, Paris

Harvey MB, Arcellana-Panlilio MY, Zhang X, Schultz GA and Watson AJ (1995) Expression of genes encoding antioxidant enzymes in preimplantation mouse and cow embryos and primary bovine oviduct cultures employed for embryo coculture Biology of Reproduction 53 530-538

Hay-Schmidt A, Viuff D and Hyttel P (1997) Transcription in in vivo produced bovine zygotes and embryos Theriogenology 47215 (Abstract)

Heid HW, Schmidt A, Zimbelmann R, Schafer S, Winter-Simanowski S, Stumpp S, Keith M, Figge U, Schmolzer M and Franke WW (1994) Cell type-specific desmosomal plaque proteins of the plakoglobin family: plakophilin 1 (band 6 protein) Differentiation 58 113-131
Hernandez-Ledezma JJ, Sikes JD, Murphy CN, Watson AJ, Schultz GA and Roberts RM (1992) Expression of bovine trophoblast interferon in conceptuses derived by in vitro techniques Biology of Reproduction $47374-380$

Herrler A, Lucas-Hahn A and Niemann H (1992) Effects of insulin-like growth factor-I on in vitro production of bovine embryos Theriogenology $371213-$ 1224

Ho Y, Doberty AS and Schultz RM (1994) Mouse preimplantation embryo development in vitro: effect of sodium concentration in culture media on RNA synthesis and accumulation and gene expression Molecular Reproduction and Development 38 131-141

Ho Y, Wigglesworth K, Eppig JJ and Schultz RM (1995) Preimplantation development of mouse embryos in KSOM: augmentation by amino acids and analysis of gene expression Molecular Reproduction and Development 41 232-238

Hogan A, Heyner S, Charron MJ, Copeland NG, Gilbert DJ, Jenkins NA, Thorens B and Schultz GA (1991) Glucose transporter gene expression in early mouse embryos Development 113 363-372

Huarte J, Belin D, Vassalli A, Strickland S and Vassalli J-D (1987) Meiotic maturation of mouse oocytes triggers the translation and polyadenylation of dormant tissue-type plasminogen activator mRNA Genes and Development 1 1201-1211

Hyttel P, Viuff D, Avery B, Laurincik J and Greve T (1996) Transcription and cell cycle-dependent development of intranuclear bodies and granules in two-cell bovine embryos Journal of Reproduction and Fertility 108 263-270

Imakawa K, Hansen TR, Malathy P-V, Anthony RV, Polites HG, Marotti KR and Roberts RM (1989) Molecular cloning and characterization of complementary deoxyribonucleic acids corresponding to bovine trophoblast protein-1: a comparison with ovine trophoblast protein- $\mathrm{I}$ and interferon- $\alpha_{\mathrm{II}}$ Molecular Endocrinology 3 127-139

Jackson RJ and Standart N (1990) Do the poly(A) tail and 3' untranslated region control mRNA translation? Cell 62 15-24

Javed MH and Wright RW, Jr (1991) Determination of pentose phosphate and Embden-Meyerhof pathway activities in bovine embryos Theriogenology 35 1029-1037

Johnson MH and Nasr-Esfahani MH (1994) Radical solutions and cultural problems: could free oxygen radicals be responsible for the impaired development of preimplantation mammalian embryos in vitro? BioEssays 16 $31-38$

Khurana N and Niemann H (1992) Energy metabolism of bovine oocytes matured and fertilized in vitro. Proceedings of the 12th International Congress on Animal Reproduction and AI The Hague, The Netherlands, August 1992 pp 348-350

Kidder GM (1992) The genetic program for preimplantation development Developmental Genetics 13 319-325

Koch PJ, Goldschmidt MD, Zimbelmann R and Franke WW (1991) Complete sequence of the desmoglein precursor and evidence for the existence of different desmoglein genes expressed in cell type-specific patterns $E M B L$ GenBank X58466

Koch PJ, Goldschmidt MD, Zimbelmann R, Troyanovsky R and Franke WW (1992) Complexity and expression patterns of the desmosomal cadherins Proceedings of the National Academy of Sciences USA 89 353-357

Kopecny V, Flechon JE, Camous S and Fulka J (1989) Nucleologenesis and the onset of transcription in the eight-cell bovine embryo: fine-structural autoradiographic study Molecular Reproduction and Development 17990

Kruip ThAM and denDaas JHG (1997) In vitro produced and cloned embryos: effects on pregnancy, parturition and offspring Theriogenology 47 43-52

Lash JA, Critser ES and Pressler ML (1990) Cloning of a gap junctional protein from vascular smooth muscle and expression in two-cell mouse embryos Joumal of Biological Chemistry $26513 \quad 113-13117$

Lee S, Gilula NB and Warner AE (1987) Gap junctional communication and compaction during preimplantation stages of mouse development Cell $\mathbf{5 1}$ $851-860$

Legan PK, Yue KKM, Chidgey MAJ, Holton JL, Wilkinson RW and Garrod DR (1994) The bovine desmocollin family: a new gene and expression patterns reflecting epithelial cell proliferation and differentiation Journal of Cell Biology $126507-518$

Lequarre AS, Grisart B, Moreau B, Schuurbiers N, Massip A and Dessy F (1997) Glucose metabolism during bovine preimplantation development: analysis of gene expression in single oocytes and embryos Molecular Reproduction and Development 48 216-226

Liu Z and Foote RH (1997) Effects of amino acids and $\alpha$-amanitin on bovine embryo development in a simple protein-free medium Molecular Reproduction and Development $46278-285$ 
Lo CW and Gilula N (1979) Gap junctional communication in the preimplantation mouse embryo Cell 18 399-409

McLachlin JR, Caneney S and Kidder GM (1983) Control of gap junction formation in early mouse embryos Developmental Biology 98 155-164

Moore GD, Takuya A, Kopf GS and Schultz RM (1996) Temporal patterns of gene expression of G1-S cyclins and cdks during the first and second mitotic cell cycles in mouse embryos Molecular Reproduction and Development 45 264-275

Morita Y, Tsutsumi O, Oka Y and Taketani Y (1994) Glucose transporter GLUT I mRNA expression in the ontogeny of glucose incorporation in mouse preimplantation embryos Biochemistry and Biophysical Research Communications 199 1525-1531

Nishi M, Kumar N and Gilula N (1991) Developmental regulation of gap junction gene expression during embryonic development Deveiopmental Biology 146 117-130

Nover L and Scharf KD (1991) Heat shock proteins. In Heat Shock Response pp 41-127 Ed. L Nover. CRC Press, Boca Raton, FL

Pantaleon M and Kaye PL (I996) IGF-I and insulin regulate glucose transport in mouse blastocysts via IGF-I receptor Molecular Reproduction and Development $4471-76$

Parrish JJ, Susko-Parrish JL, Leibfried-Rutledge ML, Critser ES, Eyestone WH and First NL (1986) Bovine in vitro fertilization with frozen-thawed semen Theriogenology 25 591-600

Parrish JJ, Susko-Parrish JL, Winer MA and First NL (1988) Capacitation of bovine sperm by heparin Biology of Reproduction 38 1171-1180

Pavlok A, Lucas-Hahn A and Niemann H (1992) Fertilization and developmental competence of bovine oocytes derived from different categories of antral follicles Molecular Reproduction and Development 31 63-67

Paynton BV and Bachvarova R (1994) Polyadenylation and deadenylation of maternal mRNAs during oocyte growth and maturation in the mouse Molecular Reproduction and Development 37 172-180

Paynton BV, Rempel R and Bachvarova R (1988) Changes in state of adenylation and time course of degradation of maternal mRNAs during oocyte maturation and early development in the mouse Developmental Biology $\mathbf{1 2 9}$ $304-314$

Pinyopummintr T and Bavister BD (1991) In vitro-matured/in vitro-fertilized oocytes can develop into morulae/blastocysts in chemically defined, proteinfree culture media Biology of Reproduction 45 736-742

Pinyopummintr T and Bavister BD (1994) Development of bovine embryos in a cell-free culture medium: effects of type of serum, timing of its inclusion and heat inactivation Theriogenology 41 1241-1249

Plante L, Plante C, Shepherd DL and King WA (1994) Cleavage and ${ }^{3} \mathrm{H}$-uridine incorporation in bovine embryos of high in vitro developmental potential Molecular Reproduction and Development 39 375-383

Prather RS and First NL (1993) Cell-to-cell coupling in early-stage bovine embryos: a preliminary report Theriogenology $39561-567$

Raabe T, Bollum FJ and Manley JL (1991) Primary structure and expression of bovine poly(A) polymerase Nature $353 \quad 229-234$

Rambhatla L and Latham KE (1995) Strain-specific progression of $\alpha$-aminitin treated mouse embryos beyond the 2-cell stage Molecular Reproduction and Development 41 16-19

Rieger D, Loskutoff NM and Betteridge KJ (1992a) Developmentally related changes in the uptake and metabolism of glucose, glutamine and pyruvate by cattle embryos produced in vitro. Reproduction Fertility and Development 4 $547-557$

Rieger D, Loskutoff NM and Betteridge KJ (1992b) Developmentally related changes in the metabolism of glucose and glutamine by bovine embryos produced and co-cultured in vitro. Journal of Reproduction and Fertility 95 585-595

Salles FJ and Strickland S (1995) Rapid and sensitive analysis of mRNA polyadenylation states by PCR PCR Methods and Applications 4 317-321

Schwarz M, Owaribe K, Kartenbeck I and Franke WW (1991) Desmosomes and hemidesmosomes: constitutive molecular components Annual Review of Cell Biology $6461-491$
Shim C, Kwon HB and Kim K (1996) Differential expression of laminin chain-specific mRNA transcripts during mouse preimplantation embryo development Molecular Reproduction and Development $\mathbf{4 4} 44-55$

Takagaki Y, Ryner LC and Manley JL (1988) Separation and characterization of a poly $(A)$ polymerase and a cleavage/specificity factor required for premRNA polydenylation Cell 52 731-742

Takahashi $Y$ and First NL (1992) In vitro development of bovine one-cell embryos: influence of glucose, lactate, pyruvate, amino acids and vitamins Theriogenology $37963-978$

Telford NA, Watson AJ and Schultz GA (1990) Transition from maternal to embryonic control in early mammalian development: a comparison of several species Molecular Reproduction and Development $2690-100$

Temeles GL and Schultz RM (1997) Transient polyadenylation of a maternal mRNA following fertilization of mouse eggs Journal of Reproduction and Fertility $109223-228$

Thompson JG, Gardner DK, Pugh PA, McMillan WH and Tervit HR (1995) Lamb birth weight is affected by culture system utilized during in vitro preelongation development of ovine embryos Biology of Reproduction 53 13851391

Trounson A, Pushett D, MacLellan LJ, Lewis I and Gardner DK (1994) Current status of IVM/IVF and embryo culture in humans and farm animals Theriogenology 41 57-66

Valdimarsson G, De Sousa PA, Beyer EC, Paul DL and Kidder GM (1991) Zygotic expression of the connexin 43 gene supplies subunits for gap junction assembly during mouse preimplantation development Molecular and Reproduction Development 30 18-26

Van Langendonckt A, Donnay I, Schuurbiers N, Auquier P, Carolan C, Massip A and Dessy F (1997) Effects of supplementation with fetal calf serum on development of bovine embryos in synthetic oviduct fluid medium Journal of Reproduction and Fertility 109 87-93

Vassalli J-D, Huarte J, Belin D, Gubler P, Vassalli A, O'Connell ML, Parton LA, Rickles RJ and Strickland S (1989) Regulated polyadenylation controls mRNA translation during meiotic maturation of mouse oocytes Genes and Development 3 2163-2171

Vernet M, Cavard C, Zider A, Fergelot P, Grimber G and Briand P (1993) In vitro manipulation of early mouse embryo induces HIVI-LTRlacZ transgene expression Development 119 1293-1300

Viuff D, Avery B, Greve T, King WA and Hyttel P (1996) Transcriptional activity in in vitro produced bovine 2- and 4-cell embryos Molecular Reproduction and Development 43 171-179

Wahle E (1991) Purification and characterization of a mammalian polyadenylate polymerase involved in the 3 ' end processing of messenger RNA precursor fournal of Biology and Chemistry 266 313I-3139

Watson AJ, Hogan A, Hahnel A, Wiener KF and Schultz GA (1992) Expression of growth factor ligand and receptor genes in the preimplantation bovine embryo Molecular Reproduction and Development 31 87-95

Winger QA, de los Rios P, Han VKM, Armstrong DT, Hill DJ and Watson AS (1997) Bovine oviductal and embryonic insulin-like growth factor binding proteins: possible regulators of 'embryotrophic' insulin-like growth factor circuits Biology of Reproduction 56 1415-1423

Worrad DM and Schultz RM (1997) Regulation of gene expression in the preimplantation mouse embryo: temporal and spatial patterns of expression of the transcription factor Sp1 Molecular Reproduction and Development 46 268-277

Wrenzycki C, Herrmann D, Carnwath JW and Niemann H (1996) Expression of the gap junction gene connexin $43(\mathrm{Cx} 43)$ in preimplantation bovine embryos derived in vitro or in vivo. Journal of Reproduction and Fertility 108 $17-24$

Yue KKM, Holton JL, Clarke JP, Hyam JLM, Hashimoto T, Chidgey MAJ and Garrod DR (1995) Characterization of a desmocollin isoform (bovine DSC3) exclusively expressed in lower layers of stratified epithelia Journal of Cell Science 108 2163-2173 